\title{
Referrals from general practice to hospital outpatient departments: a strategy for improvement
}

\author{
John Emmanuel, Nigel Walter
}

\begin{abstract}
Objective-To determine the appropriateness of referrals from general practice to hospital outpatient departments.

Design-Prospective audit of referrals from a group practice over one year.

Setting - Six handed practice in a southern coastal town.

Subjects-All patients referred during the study period for whom a copy of the referral letter was available.

Main outcome measures-The investigations carried out by the consultant that led to the diagnosis; the diagnosis reached; and the management.

Results - Of roughly 3000 patients referred during the year, 277 with various skin and soft tissue disorders could probably have been managed solely by the general practitioner. Referrals for cryotherapy (96 in this series) and diabetes (19) could probably also have been avoided by specialist training of the general practitioner. In addition, in cases of haematuria and prostatic hypertrophy (34 and 22 referrals) substantial time could have been saved for both the patient and the consultant had the general practitioner supplied the results of relevant investigations. Probably the most important outcome was the model that the study offered for other general practitioners to improve the appropriateness of referrals.

Conclusion-This approach to determining the appropriateness of referrals benefits the general practitioners, the consultant, and the patient.
\end{abstract}

\section{Introduction}

In 1986 our six partner practice published its first annual report. A surprising statistic was that the practice had generated more than 3000 referrals to the local NHS outpatient clinics during the previous 12 months. We thought that this would be a fruitful topic for further research, particularly against a background of a growing national interest in the unexplained wide variation in referral rates throughout Britain.

The subject remains topical with claims of a 20 -fold variation in general practitioner referral rates, ' though a recent study reduced this to a fourfold difference when bias due to random variation and small sampling numbers was taken into account. ${ }^{2}$ These figures have attracted the attention of the Department of Health with the inevitable temptation to make value judgments on what constitutes an appropriate referral rate based on numerical audit alone.

We were also aware of the many published studies that had unsuccessfully attempted to explain the variation in referral rate by comparing the personal characteristics of doctors who were high referrers with those who were low referrers. None of those studies yielded any positive correlations.
We concluded that the published research to date had been interesting but of little practical value to general practitioners wishing to examine the appropriateness of their own referrals. Hence we decided to approach the question in a different way-namely, to record the conditions that we were referring, to note the outcome of those referrals, and, with this information, to discuss our referral behaviour with our consultant colleagues.

\section{Present study}

On 1 July 1987 we started a one year prospective audit of referrals from our practice to local NHS clinics. We knew that to mount such a study on an expected 3000 referrals would be time consuming and expensive, particularly as a computer would be needed to sort data. At the time the South East Thames Regional Health Authority had just announced its Primary Care Development Fund to promote general practice research. We were fortunate enough to be successful in our application for a $£ 12000$ grant to fund the project.

We hoped that our work might provide information of practical value to colleagues locally and also serve as a possible model for use in other health districts. We were encouraged by the findings of Marinker et al (published six weeks after the end of our audit), who wrote: "Numbers and rates do not tell us enough in themselves to allow us to form judgments about what is desirable. For this it is necessary to look at the appropriateness of referrals in terms of their actual or expected outcomes.",

\section{Method}

Between 1 July 1987 and 30 June 1988 a copy of every referral letter typed was filed separately. Each letter was read by one of us and the principal reason for the referral identified and registered in the form of a keyword. Some keywords were specific (for example, "keratosis"); others indicated a more general symptomatic presentation (for example, "painful shoulder"). The use of keywords allowed us to reduce the 3000 individual referrals to 215 manageable groups. With the keyword highlighted, each referral letter was given to our computer operator, who entered the details in a standard format which included the patient's identification code, the consultant to whom the patient was referred, and the keyword.

The next phase was to record the outcome of each referral when the patient was seen at the outpatient department, and for this we enlisted the cooperation of our partners. They were asked when reading their daily correspondence to record the details of every hospital letter in a book. The following three column format was used: the investigations carried out by the consultant that led to the eventual diagnosis (I); 
the diagnosis reached $(\mathrm{D})$; the management $(\mathrm{M})$. By using the "IDM" format the outcome of every referral was entered into the computer, allowing easy analysis of the results. To.include as many outcomes as possible we continued to collect data for three months after the close of the project.

Using the sorting capability of the computer we provided for each of the 35 consultants in the Hastings Health District a printout of the conditions that we had referred during the 12 months, complete with their outcomes. We then arranged a meeting with each consultant individually and in the course of informal discussion made notes of our conclusions on which to base guidelines for efficient referral.

For each group of referred conditions identified by one of our keywords we tried to ascertain $(a)$ how the receiving consultant perceived the appropriateness of the referral, $(b)$ what information the consultant would have liked included in the referral letter, $(c)$ what investigations should have been done before outpatient attendance, and $(d)$ whether the general practitioner could have managed the case better before referral

\section{Results}

PERSONAL AUDIT

The project enabled us to audit our own performance as a practice in respect of hospital referrals. We recorded every referral over the 12 months and the outcome of each. Discussions with local hospital colleagues suggested that in their opinion most of the conditions that we had referred were appropriate for hospital management. Nevertheless, there were some aspects in which we thought that our referral behaviour should change. For example, to the dermatologists we referred 89 patients with undefined skin lesions, 55 with keratoses, 56 with warts, 28 with sebaceous cysts, and 18 with verrucas. These figures confirmed that in our practice there was a need for a session for minor surgery. (We have now begun such a session, which we hope to extend soon to include cryotherapy.) Soft tissue disorders (31 referrals) and diabetes (19) were other conditions in which we should like to increase the scope of our management skills (table).

Referrals suitable for management by the general practitioner

\begin{tabular}{lc|lc}
\hline & $\begin{array}{c}\text { No of } \\
\text { referrals }\end{array}$ & & $\begin{array}{c}\text { No of } \\
\text { referrals }\end{array}$ \\
\hline Undefined skin lesions & 89 & Veruccas & 18 \\
Keratoses & 55 & Soft tissue disorders & 31 \\
Warts & 56 & Diabetes & 19 \\
Sebaceous cysts & 28 & Cryotherapy & 96 \\
\hline
\end{tabular}

\section{GUIDELINES FOR GENERAL PRACTITIONERS}

Possibly the most tangible result of the project was a handbook containing a distillation of our discussions with the local consultants (Emmanuel J, Walter N. Referral Guide (pending publication)). The handbook offers guidelines about efficient referring in terms of relevant history, investigations, and suggestions to allow general practitioners to manage some of the conditions themselves. Use of the handbook. could help in ensuring that each referral made the most effective and economical use of both the consultant's and the patient's time.

The following illustrates the practical value of the handbook. In urology haematuria and prostatic hypertrophy are common problems (34 and 22 patients respectively referred in this series). Cystoscopy is now feasible in the outpatient department under local anaesthesia. Thus if a general practitioner offered the results of the required investigations for haematuria in many cases the patient could be processed in one outpatient attendance. Similarly, if the relevant investigations for prostatic hypertrophy were done by the general practitioner the patient might be admitted to the waiting list in one visit. The handbook lists the relevant history, examination, and investigations for prostatic hypertrophy as: degree of obstructive symptoms and any symptoms of localised pain or ill health; digital examination of the prostate; and full blood count and urea and electrolyte estimations, examination of midstream urine specimen, plain radiography of kidneys, ureters, and bladder, and bladder ultrasonography. Common investigations listed as less helpful (and therefore unnecessary) are: intravenous urography (unless there is pain or bleeding); serum alkaline phosphatase activity (not specific; does not affect management); and test for prostate specific antigen (not diagnostic; false positive result leads to unnecessary biopsy).

The handbook also provides diagnostic pointers. In addition to those for benign skin conditions, use of the guidelines for differential diagnosis of keratoses would reduce unnecessary referrals, thereby freeing the specialist for more appropriate conditions. Practical guidelines like this are provided in every specialty. We intend to distribute a copy of the handboook to every general practitioner in the Hastings Health District and hope for a dramatic impact on referral behaviour.

\section{MODEL FOR AUDIT}

Possibly the most important outcome of the project was the model that it offered for general practitioners in other areas to audit and improve their hospital referrals. Plainly the handbook that we have prepared is appropriate for the Hastings Health District and may not be transferable to other areas. Nevertheless, the model could be used by groups of general practitioners and hospital colleagues in any health district in the United Kingdom. The model is simple:

(1) Audit conditions referred to hospital. (We found that one or two of our local consultants were routinely doing this.)

(2) Decide whether any conditions currently referred could be managed in general practice by acquiring extra skills or providing staff or time.

(3) Agree protocols for referral information, helpful investigations, and management strategies by the general practitioner.

(4) Review and update protocols annually.

\section{Discussion}

Outpatient referrals form the main interface between general practice and hospital. Patients might justifiably expect their general practitioner to have provided the consultant with all the necessary information required to reach an early diagnosis or management plan in the minimum of hospital visits. We found that consultants had clear ideas of the information they required for most cases referred, and an exercise such as the present one has enabled us to set standards for efficient referral behaviour.

We think that we have produced a valuable piece of research, but at the cost of considerable time and money. We were fortunate in receiving a $£ 12000$ grant from South East Thames Primary Health Care Development Fund. The equipment alone accounted for a considerable proportion of this grant, the amount of data processed needing an elaborate software database package and the hardware to handle it. The cost in time was considerable, both for ourselves and in secretarial support, and these factors must be given due weight if audit in any depth is to be expected from general practitioners.

Set against the cost of the research the rewards to us 
were substantial. Apart from limited deficiencies in our referral behaviour, which we were probably aware of for example, in respect of dermatological and soft tissue disorders-and which we shall now correct, there was no evidence of appreciable overreferral. Consultant colleagues showed a gratifying understanding of the covert reasons for some referrals-for example, reassurance of healthy but anxious patients or reassurance of the general practitioner with an undefined sense of unease about symptoms in a patient - and therefore their appropriateness.

Underreferral could be defined accurately only by proper analysis of alternative routes to treatment-for example, attendance at an accident and emergency department or short term admission for a pre-existing problem - which was beyond the scope of our project. The consultants, however, were unable to identify any condition in which underreferral was a problem, though they suggested more efficient methods of referral in some cases-for example, for urgent eye conditions. Thus as a result of our audit probably the number of referrals will drop only slightly but the quality should be improved and the management of patients should become more efficient.
We suggest that this approach to hospital referral is an educational exercise benefiting the general practitioner, the consultant, and the patient and could form the basis of regional auditing of the appropriateness of referrals. Any discussion of the appropriateness of referrals, whether by doctors, administrators, or government, should take place against an informed background rather than with non-evaluated and uncorrected statistics such as individual doctors' referral rates. Such audits, however, are expensive in time and money. Therefore, it is important that realistic funding should be provided if audit is to be undertaken at this level.

We could not have completed this project without the help and tolerance of our partners and staff. Special thanks are due to Sally Wilson, who bore the brunt of computer work.

1 Secretaries of State for Health, Wales, Northern Ireland, and Scotland. Working for putients. London: HMSO, 1989. (Cmnd 555.)

2 Moore AT, Roland MO. How much variation in referral rates among general practitioners is due to chance? Br Med 7 1989:298:500-2.

3 Marinker M, Wilkin D, Metcalfe DH. Referral to hospital: can we do better? Br Med f 1988;297:461-4.

(Accepted 9 August 1989)

\section{BOOKS RECEIVED}

\section{AIDS}

AIDS and AIDS-related Infections: Current Strategies for Prevention and Therapy. [Based on a meeting of the British Society for Antimicrobial Chemotherapy, Stratford-on-Avon, 21-22 April 1988.] Ed A J Bint, Oxford, P J Daly. (Pp v +137 ; figs £12.50 paperback.) London: Academic Press, 1989. Distributed by Harcourt Brace Jovanovich. ISBN 0-12-0992200-0.

AIDS Clinical Review 1989. Ed P Volberding, M A Jacobson. (Pp xviii 252; figs; $\$ 107.50$.) New York: Dekker, 1989. ISBN 0-8247-8105-8. AIDS: Scientific and Social Issues: Resource for Health Educators. [Also available as part of the 'Learning About AIDS' pack. IP Aggleton, $\mathrm{H}$ Homans, J $S$. Mojsa, S Watson, S Watney. (Pp Churchill Livingstone, 1989. ISBN 0-443-04182-2.

Learning About AIDS Pack. Exercises HIV infection and AIDS. Pack co ains an introductory brochure + book AIDS: Scientific and Social Issuesa Resource for Health Educators' + Learning About AIDS Exercises exercises and worksheets in lowselea format with format, with wallet. P Aggleton, H Homans, J Mojsa, S Watson, Watney: The pack costs 119.95 . 1989. ISBN 0-443-04181-4.

The Science of AIDS: Readings from the Scientific American Magazine. Ed J Piel. (Pp vii + 135; figs; colour figs; £7.95 paperback.) New York: Freeman, 1989. ISBN 0-7167-2036-1. Series in Death Education, Aging, and Health Care. Reference edition. "AIDS: Principles, Practices, and Politics." Ed I B Corless, M PittmanLindeman. Consulting editor $\mathrm{H}$ Was (Ppxxix + 583; £58.) New York: Hem sphere, 1989. ISBN 0-89116-716-1.

Alternative medicine

The Whole Truth: the Myth of Alternutive Health. R Coward. ( $P p$ vi 216 £12.99.) London: Faber and Faber, 1989. ISBN 0-571-14114-5.

\section{Blood pressure}

Concepts in Hypertension: Festschrift for Sir Stanley Peart. [Meeting, Como, Italy.] Ed C J Mathias, P S Sever. (Pp xii+119; figs; paperback, price not stated.) Darmstadt: Steinkopff/New York: Springer, 1989. ISBN Steinkopff: 3-7985-07+9-X, Springer: $0-387-91314-9$.

\section{Cardiology}

Complications of Cardiac Catheterization and Angiography: Prevention and Management Ed J Kron, M J Morton. Management. Ed J Kron, $M$ J Morton. Pp viii +393; figs; \$55.) New York: Futura, 1989. ISBN 0-87993-338-0.

Heart Disease: Review and Assessment. A Question and Answer Book with Explanations and References. M E Mendelsohn, B C Berk. Ed E Braunwald. (Pp 230; figs; £22.95 paperback.) Philadelphia: Saunders, Jovanovich. ISBN 0-7216-2242-9.

Primer on Laser Angioplasty. R Ginsburg, J C White. (Pp x+303; figs 447.) New York: Futura, 1989. ISBN 0-87993-329-1.

\section{Clinical chemistry}

Multiple Choice Questions and Case Histories in Clinical Chemistry. D McDowell, C Weinkove. (Pp vi+ 154; 24.95 paperback.) Manchester: Manchester University Press, 1989.

\section{Diabetes}

Positive Health Guides. "Diabetes and Pregnancy." A Knopfler. (Pp viii + 168; figs; $£ 5.99$ paperback.) London Macdonald Optima, 1989. ISBN 0-356-15189-1.

\section{Disabled/handicapped people}

Disablement in the Community. Ed D L Patrick, H Peach. (Pp xvii +230; figs: £17.50 paperback.) Oxford: Oxford University Press, 1989. ISBN 0-19. 261434-7.

\section{Disasters}

Coping with Natural Disasters: the Role of Local Health Personnel and the Community. World Health Organisation. (Pp x+98; figs; 114.40 paperback.) Geneva: World Health Organisation, 1989. ISBN 92-4-154238-1.

\section{Ear, nose, and throat}

Otolaryngic Allergv and Immunology. $\mathrm{H}$ F Krause. (Pp xii +318 ; figs; $\mathfrak{1 4 5}$.) Philadelphia: Saunders, 1989. Distri- buted by Harcourt, Brace Jovanovich. ISBN 0-7216-2867-2.

\section{Genetics}

Oxford Monographs on Medical Genetics. 16. "Garrod's Inborn Factors in Disease." [Including an annotated Discase." Ihcluding an annotated facsimile reprint of "The Inborn Fac tors in Disease" by A E Garrod.] C R
Scriver, B Childs. (Pp xiv + 248; figs; Press, 1989. ISBN 0-19-261574-2.

\section{Health care issues}

Frontier Medicine. New Medical Tech niques and the Consumer: a Discussion Paper. C Hogg. (Pp vit 102; £5 paperback.) 1988. Greater London Association of Community Health Councils, 100 Park Village East, London NW 3SR. ISBN 0-950737-34.

Health and Efficiency: a Sociology of Health Economics. M Ashmore, $M$ Mulkay, T Pinch. (Pp xii +224; figs: f10.95 paperback.) Milton Keynes: Open University Press, 1989. ISBN 0-335-09912-2

Managing Psychiatric Services in Transition: King's Fund Working Papers: Ed D) Towell, $S$ Kingsley, T McAusland. (Seven hooklets in wallet; 58.95 paperback.) London: King's Fund, 1989. ISBN 1-870551-88-5.

The NHS Review: What it Means. Articles published in the British Medical foumal. (Pp vi +73 ; figs $£ 4.50$, overseas $£ 6$ paperback, includ ing postage, airmail overseas). BMA members $£ 4$, overseas $£ 5.50$ includin postage London: British Medical foumal, 1989. In North America available from the American College of Phe ricm the American College of Philan, PO Box 7777-R-0270, 0-7279-0271-7.

\section{Microbiology}

Appleton and Lange's Review of Micro biology and Immunology. W W Yotis, H J Blumenthal, T Hashimoto. (Pp xiii 146; £16.75 paperback.) Connecticut: Appleton and Lange, 1989. Distributed by Prentice Hall International. ISBN 0-8385-0217-2.

\section{Neurology}

Clinical Atlas of Auditory Evoked Potentials. J H Owen, C D Donohoe. (Pp xi+119; figs; £27.95.) Orlando:
Grune and Stratton, 1989. Distributed by Harcourt Brace Jovanovich. ISBN 0-8089-1896-6,

Topics in Neurosurgery. "Advanced Evoked Potentials." Ed H Lüders. (PP ix +278 ; figs; colour plate; $£ 52.50$. Boston: Kluwer Academic, 1989. ISBN 0-89838-963-1.

\section{Neurosurgery}

The Diagnosis and Management of Orbital Tumors. Ed E R Laws Jr. (Pp xiv +316 ; figs; \$55.) New York: Futura, 1988. ISBN 0-87993-304-6.

\section{Nutrition}

Comparative Animal Nutrition. Vol 6 . "Use of Animal Models for Researc in Human Nutrition." Volume an series editors A C Beynen, C E West. Pp vi+190; figs; £76.40.) Base: Karger, 1988. Distributed by Joh Wiley and Sons. ISBN 3-8055-4802-8. The Story of Iodine Deficiency: an Inter national Challenge in Nutrition. B S Hetzel. (Pp xii +236 ; figs; 118.50 ) Oxford: Oxford University Press, 1989. ISBN 0-19-261669-2.

WHO Regional Publications, European Series, No 24. "Healthy Nutrition: Preventing Nutrition-Related Diseases in Europe." W P T James. Pp xiii 150; figs; Sw frs 20 paperback.) Copen50; figs; Sw frs 20 paperback.) Copenhagen: World Health Organisation Regional Office for
ISBN 92-890-1115-7.

\section{Pathology}

Major Problems in Pathology. Vol 20 "Disorders of the Spleen." B C Wolf, R S Neiman. Consulting editor J L Bennington. (Pp xvi+211; figs and colour plates; $\{37.50$.) Philadelphia: Saunders, 1989. Distributed by Harcourt Brace Jovanovich. ISBN 07216-2503-7.

\section{Perinatal medicine}

Reviews in Perinatal Medicine. Vol 6. Ed E M Scarpelli, E V Cosmi. (Pp xiii+239; figs; \$96.) New York: Liss, 1989. Distributed by John Wiley and Sons. ISBN 0-8451-0401-2.

\section{Rheumatology}

Rheumatology. The Interdisciplinary Concept. Vol 12. "Rheumatoid Arthritis Surgery of the Shoulder." Ed A W F Lettin, C Petersson. Series 